months, and that the UNHCR will have some sort of decision-making role on the special commission convened for this purpose.

\section{Final Comments}

It appears that it is the deliberate policy of both the UNHCR and the GoD to keep refugees ignorant of their current status and entitlement to protection in Djibouti. The refugees' concern that the repatriation programme is being targetted largely at the political rather than the rural refugees has been rubbished by the UNHCR, who meanwhile hold the view that refugees who leave the territory under the pressure of this campaign, were only fortunehunters in the first place. This is not borne out by the evidence. The fact that individuals will choose to put their lives in danger through the hazardous routes they are forced to take to leave Djibouti rather than risk protection being withdrawn and forced repariation strongly implies both that their reasons for being in Djibouti are genuine, and that their fears of repatriation are real.

There has been a total breakdown of confidence in the UNHCR on the part of the refugees, who perceive the agency to be a lackey of the GoD, which in turn is perceived to be eager and willing to ingratiate itself with the Dergue by returning its political opponents.

The attitude adopted by the UNHCR is in keeping with the general hardening of line noted within it since the arrival of the new High Commissioner. This is of particular concern in relation to the status of asylum seekers, whose attestations became invalid as of December 31st. The UNHCR appears to accept no responsibility for these peoples' plight despite the fact that any Ethiopian who would seek asylum in Djibouti during a repatriation exercise must have extremely compelling reasons for doing so.

It can be reasonably assumed that the repatriation exercise is nearly over and that at the end of it around 2,000 Afars and 3,2004,000 Issas will be left in Dikhil camp with the tacit permission of the GoD. Having got rid of the Gurguras, the group of rural refugees which was perceived as being undesirable, it will now be important to monitor what further measures, if any, will be brought against the political refugees, and to what extent the UNHCR, within the context of the special eligibility commission, is willing and able to assure their protection.

The introductory background presentation preceding the bulk of this report was prepared by Barbara E. Harrell-Bond.

\title{
Improving the Standards of Human Rights and Refugee Protection in Africa
}

\author{
by Barbara E. Harrell-Bond and George Kanyeihamba
}

\section{Introduction}

In September 1986, under the auspices of the refugee Studies Programme, an international seminar on the implementation of the OAU and UN Coaventions and Domestic Legislation Concerning the Rights and Obligations of Refugees in Africa was held at Oxford Univerity. There were thirty-five participants from Africa, including academics and officials nominated by seventeen African govemments. A aumber of eminent scholars, government officials, refugees, and agency personnel from Asia, Europe and the Americas were involved. The seminar focused chiefly on refugees in Africa, but one of its pupposes was to acquaint participants with law, policy, and practice in all the regions of the world affected by mass exodus. Each African govemment representative presented a paper on the legal situation for refugees in their country.

Guest speakers reported on the situation for refugees in Southeast Asia, Pakistan, Canada, Europe, Central America, Britain, the US, and Mexico. Through films and lecures, the paricipants were able to consider a range of related topics: for instance, how different development models lead to oppression; the psychological consequences of authoritarian regimes; the rights of the child; the special problems of women refugees; wrture; and the problems of adaptation to life in asylum.

\section{The Theme}

The overall theme was the law relating to the rights and obligations of refugees in African host countries. The participants were encouraged to contribute to discussions in their personal, rather than their official capacity, so that the recommendations arising from the seminar would provide fresh, insights and influence positive change. Emphasis was placed on the elucidation of the practice of govemments, officials, and field workers racher than on the theoretical norms prescribed by law.

\section{The Law of Refugees}

Zia Rizvi, Secretary-General of the Independent Commission on Intemational Humanitarian Issues, opened the seminar with the keynote address entitled "New Dimensions of Uprookedness", which ser one of the major themes of the meeting, i.e. the changing character of the problem of forced migration today which has moved beyond the capacity of either laws or present approaches to assistance to alleviate. In a second introductory address, George Kanyeihambe reminded the audience that the standards and concepts embodied in intemational human rights law were nor an imposition of any one civilization, but rather reflect the values which arise from the best values in all societies.
Y. Makonnen, of the UNHCR, and I.C. Mponzi of the OAU, led the discussion on the OAU Convention conceming refugees. Africa has made innovative contributions to the law and practice of refugee protection and assistance, including its own definition of the term "refugee" propounded in the 1969 OAU Refugee Convention, which is broader that that contained in the UN instruments. Iss standards are having a positive impace on other regions of the world.

\section{The Hosts' Experience}

Throughout the two weeks considerable time was given to discussion of refugee issues from the hosts perspective. Emphasis was placed on the need for assistance which redresses the extreme poverty of local communities, who are, in many cases, as impoverished as the refugees. The presence of specialists and representatives of host countries from other regions of the world outside Africa added to the constructive, comparative, and not uncritical look at réiugee policy in different countries. This was particularty the case when refugee policies in Europe and North America were discussed.

Not all countries represented were parties to the intemational conventions on refugees, namely the 1951 Refugee Convention, its 1967 Protocol and the 1969 OAU Refugee Convention. Some have no domestic legislation, although practice was sometimes in conformity to the Conventions. There were also differences between African countries in terms of which Ministry was responsible for implementing refugee law. In many cases, the concentration of African government of ficials was on status determination, rather than on administering assistance, despite the fact that most refugees in Africa are granted refugee status en masse.

\section{The Refugee Experience}

A number of sessions were devoted to leaming about the refugees' own experiences through films and discussions often led by refugees themselves. These sessions were some of the most thought-provoking. Particular atuention was drawn to the difficulties experienced by refugees and the special need for sensitivity in dealing with people who have undergone extremely distressing or traumatizing experiences. Besides looking at the commonplace problems of refugees, such as insecurity, unemployment, and other forms of deprivation, the participants went on to examine the psycho-social problems of refugees and the special needs of particular groups .- namely women and children. Among the many issues raised in these sessions, the following stand out: the persecution and deprivation of refugees; their frustrations at the loss of their former socio-economic status; factionalism among 
refugees; the breakdown of social norms, paricularty such problems as challenges to family loyalties; insecurity; ill-health. In addition, discussion covered the fallacy of making the over-simplified distinction between urban and nural refugees, the unfortunate tendency of dealing with refugees with condescending paternalism, and the necessity for minimalizing hostility between refugees and local communities through public education. The necessity to avoid discrimination against the local population in matters of aid was also raised.

There were extreme differences between countries when it came to considering the topic of refugee participation, and the exsent to which refugees were permitted to take responsibility for organizing programmes for their own people. The Sudan has taken the positive step, along with some other African govermments, of formally recognizing refugee organizations and allowing them to function in the same way as other humanitarian agencies, not only in terms of importing duty-free material aid, but in taking responsibility for their communities' welfare as a whole. The SWAPO and ANC representatives were able to demonstrate to the participants the enormous advantages to the prychological health of refugee communities stemming from their being allowed to manage their own programmes of education, medical care, and income generation.

Of particular concem to the audience were the increasingly restrictionist policies of the rich nations of the world in boch mauers of granting asylum and assistance. The analysis of the reasons for these policies did not wholly satisfy the participants, particularly when they considered the depressing conditions facing refugees in the West who come from the less-developed world.

\section{Teaching Human Rights}

Participants were invited to discuss the power of the media as an instrument for curbing human rights abuses, including those of refugees. The role of the media in influencing public opinion through the use of images of helpiess refugees and famine victims in order to raise cash for humanitarian work was discussed and illustrated with films.

The complex issues related to resettlement in Westem countries were discussed and dramatically portrayed in two films: Becoming American and El Norte. Special sessions were devoled to the issues of education, publicity and the dissernination of information as well as on the implementation of law relating to human rights and refugees. Experiences of successful and innovative methods of disseminating legal information applied in Thailand and the Sudan were shared. The presenters emphasized that certain people needed to be identified and classified as target groups for education on human rights and the rights of refugees. These include govemment officials. refugees and local people. Samples of materials used to disseminate information in Thailand were shown to the participants and a useful discussion of these samples and how they are utilized followed the presentation. The experience of education and training on refugee law in the Sudan, together with the presentation on teaching human rights to police, prompted considerable discussion. Participants were convinced that it was important to extend this kind of training not only to the police, but to immigration and prison officers, social workers, church and social work leaders, administrators and the local community; this was seen as most essential to the understanding and solution of refugee problems.

The participants were encouraged to reconsider the value of non-govermmental agencies in acting as human rights watchdogs in their own countries. National and intemational organizations should be used to provide information exchange. Although participants were not wholly uncritical of the work of Amnesty Intemational, it is one of the success stories in this field. A representative presented the seminar with information about how Amnesty collects and disseminates information; he also expressed Amnesty Intemational's concern about forcible and secret repatriation and the likelihood of imprisonment. torture, or even execution for those forced to return to countries from which they had fled in the first piace.

\section{Seminar Resolutions and Recommendations}

The Seminar culminated in a series of workshops during which small groups of participants formulated specific recommendations and adopted resolutions. A draft repon of all the sessions, and the specific recommendations of the workshops, were presented at a plenary session under the chairmanship of George Kanyeihamba and, after lively discussions, were unanimously approved by the participants. Some of these resolutions break new ground.

\section{Resolutions}

1 The Seminar urges states which have not yet acceded to and/or ratified the international refugee instruments to do so.

2 The Seminar, having noted that certain states, including those which have ratified the intemational refugee instruments, have not always adhered to the rules and spirit therein, urges these states to do so.

3 The Seminar urges the states which have not yet enacted domestic legislation incorporating the international refugee instruments to do so by way of implementation and to take into account local conditions and circumstances.

4 The Seminar, having noted that certain aspects of the 1951 Refugee Convention and its 1967 Protocol are outmoded, in that the definition of the term "refugee" is too narrow due to its detachment from present-day complexities and realities inherent in the phenomenon of exile, urges states to adopt new measures which take into account the foregoing, including the wider definition contained in the OAU refugee Convention, in particular relating to refugee status, displaced persons, and burden-sharing among states.

5 The Seminar notes with regret the increasingly restrictionist application and implementation of refugee law in the world, particularly in the developed states, and urges these states to be more liberal in that regard and to refrain from using regionalism as an excuse for denying asylum and sanctuary.

6 The Seminar urges states which have not done so to establish appropriate mechanisms to implement the law, including equitable screening procedures and procedures of judicial appellate system for determination of the status, rights and obligations of refugees.

7 The Seminar urges states to encourage and promote refugees' participation and consultation in the decision-making processes which affect them.

8 The Seminar, noting that there is an important distinction between a refugee and an immigrant, urges states to reflect this distinction in their laws and implementation procedures.

9 The Seminar, noting that inequality in international and economic relations is a major cause of violations of human rights and man-made disasters that lead to the uprooting of peoples and influx of refugees, urges the international community to redress the situation in order to allow for better economic development leading to better standards of living.

10 The Seminar, noting that every nation's growth and development depends on its youth, urges states to include special provisions in their national laws for the protection of the child.

11 The Seminar urges that countries of asylum disseminate refugee law by all available means both to refugees and to people involved in the implementation of such law, such as police, immigration officers, social workers and the like.

12 The Seminar appeais to states to assume their responsibilities for the situation of refugees, including eliminating conditions which lead to refugee flows, acknowledging their role in creating refugees, and assisting in finding durable solutions.

13 The Seminar, noting that voluntary repatriation is the most appropriate durable solution in certain instances, appeals to countries or origin and the international community to create the conditions of political, economic and social stability, including cessation of armed conflicts, and respect for human rights, which will promote voluntary repatriation.

14 The Seminar recommends that states agree 
that refugees are given opportunities to investigate freely whether conditions of stability and respect for human rights have been restored in the country of asylum and country of origin without forfeiting their refugee status.

15 The Seminar condemns any violation of human rights, especially the practice of torture, and recommends that host countries establish special programmes to treat victims of torture. The Seminar urges states who have not done so to adopt and ratify the Convention on the Elimination of Torture.

16 The Seminar urges that refugees should not be placed in detention without formal criminal charges and a fair trial, according to international standards.

17 The Seminar urges that host countries promote conditions which facilitate the movement of refugees both locally and intemationally, consistent with their national security interests.

18 The Seminar appeals to the intemational community to give development assistance to host countries so that they can create conditions providing employment opportunities for refugees which benefit citizens of the host countries and refugees.

19 The Seminar deplores the use of images of refugees as helpless victims or "problems" in policy reports and fund-raising.

20 The Seminar, recogninzing that $95 \%$ of refugee matters are related to social welfare, recommends that governments ensure that provision is made for the implementation of social and economic rights.

21 The Seminar urges that field officers of various descriptions who deal directly with refugees should be given practical and relevant training in refugee law, procedure and day-to-day refugee problems.

22 The Seminar recommends that special efforts should be exerted by states, international organizations, state institutions, governmental and nongovernmental groups to identify target groups such as police, immigration officials, administrators, security officers, prison officials and religious leaders for the purposes of training them in the field of human rights and refugee law.

23 The Seminar, noting that women and children represent the majority of the refugee population, urges that women should be involved in making the decisions which affect their lives and that children should be specially protected.
24 The Seminar appeals to UNICEF, host goverments and specialized organizations to aid refugees in the design and implementation of programmes appropriate to the special needs of children in refuge and strongly recommends that these programmes take into account traditional cultural values and experiences as far as is practical.

25 The Seminar urges host countries to ensure that security of refugee settlements in general and the safety of refugee children in particular, protecting them against kidnapping and all forms of abuse.

26 The Seminar strongly condemns any armed attacks on refugees wherever they are, and further condemns those who aid and abet such attacks. The Seminar calls upon the international community to invoke the relevant UN instruments to condemn these attacks and impose the necessary sanctions.

27 The Seminar urges the UNHCR to fulfil its mandate to protect refugees by reporting all such armed attacks to the UN General Assembly.

28 The Seminar recommends that the UNHCR, the OAU, voluntary agencies and donor countries increase levels of financial and material assistance to host countries in order to augment their limited resources in catering for refugees, and in particular that the OAU Special Refugee Contingency Fund be increased.

29 The Seminar calls upon African countries which have acceded to the 1951 UN Convention, its 1967 Protocol and the 1969 OAU Convention to incorporate the principles of refugee law embodied in these instruments, and take effective measures to disseminate refugee law to officers who deal directly with refugees.

30 The Seminar notes that a major cause of refugee problems in the world is the denial of human rights. The Seminar urges those African states which have not done so to ratify the African Charter on Human and People's Rights and further urges all African states to establish mechanisms for the implementation and enforcement of the provisions of the Charter including the establishment of a Regional African Court of Human Rights to which aggrieved individuals and states can resort.

31 The Seminar urges that domestic legislation on refugees in Africa make provision for rights of appeal to courts by refugees who are aggrieved by administrative decisions.
32 The Seminar urges all states, and in particular the African states, in the spirit of African solidarity and as a way of implementing the 1979 Arusha Recommendations on the problem of refugees, undertake refugee burden-sharing, especially with respect to fronline states by virtue of the special circumstances of the refugee problem in the region.

33 The Seminar recommends that the OAU make provisions for the dissemination of information about human rights and refugee laws amongst member states.

34 The Seminar urges African states, international organizations, public states institutions, governmental and non-govemmental groups to disseminate information on human rights and refugee law.

35 The Seminar urges African countries to introduce projects for environmental protection to eliminate desertification and to increase food supply in order to lessen displacement of peoples.

36 The Seminar urges African states to observe and respect human and people's rights as embodied in the African Charter on Human and People's Rights.

37 The Seminar urges African states to improve their systems of transportation and communication links to convey early waming signals for refugee influxes, and to provide food storage facilities for refugee emergency and crisis sibuations.

38 The Seminar calls upon African states to promote research in order to carry out proper planning and management of resources for refugees.

39 The Seminar calls upon the OAU to extend its role from mere ad hoc refugee problems to comprehensive and developmental policies for refugees in Africa, and to provide information on the movement of refugees in Africa.

40 The Seminar, recognizing that the racist regime of South Africa is a major cause of refugees in Africa, calls upon all states which have not done so to accede to and/or ratify the Intemational Convention on the Suppression and Punishment of the Crime of Apartheid.

41 The Seminar, appreciating the participation of government officials at the Seminar, calls upon governments, international organizations and NGOs to take appropriate measures to implement the recommendations of this Seminar. 